\title{
ドイツ各州も大学予算に大なた
}

\section{German states wield the axe}

QUIRIN SCHIERMEIER 2010年6月24日号 Vol. 465 (966)

www.nature.com/news/2010/100622/full/465996a.html

ドイツでは、科学研究を存続させるための連邦政府の努力とは裏腹に、

一部の州政府が大学予算の削減に動いている。

ドイツの連邦政府は、科学と高等教育を 強力に支援しているが、その一方で、ド イッの公的財政の危機による犠牲者が出 始めた。財政状況の逼迫した州が、大学 予算削減の準備に着手したのだ。

6 月中旬、シュレースヴィヒ $=$ ホル シュタイン州では、数千人が州都キール に集まり、まもなく実施されるリュー ベック大学医学部の閉鎖に反対する集会 を開いた。「2011 年の冬学期から医学 部の新入生の受け入れを中止せざるを得 ないなんて言語道断です」。こう話すの は、同大学で構造ウイルス学を研究する Rolf Hilgenfeld だ。リューベック大学 に限らず、ドイツ国内の大学の研究者は、 今後の事態の悪化を心配している。

連邦政府は、 5 月に発表した数十億 ユーロ規模の公共支出削減から、ドイッ 研究振興協会 (DFG) などの国家機関 を除外した。しかし大学に対して資金助
成をしている州の多くは、助成予算の維 持に四苦八苦している。例えばへッセン 州政府は、今後 5 年間、大学予算を毎 年 3000 万ユーロ（約 34 億円）カット することを 5 月に発表した。ザクセン 州内の各大学も、同じような予算削減に 直面している。

また、シュレースヴィヒ＝ホルシュ タイン州政府は、公共支出を毎年 1 億 2500 万ユーロ（約 140 億円）削減して、 迫り来る財政赤字の穴埋めに充てるこ とを 5 月に発表した。これによって大 打撃を受けるのが、科学と高等教育だ。 リューベック大学の予算は、2015 年か ら年間予算総額の 30 パーセントに当た る 2400 万ユーロ（約 27 億円）が減額 される。この予算削減で、医学部が閉鎖 されるだけでなく、大学の存立自体が脅 かされている、と同大学の研究者は話す。

リューベック大学は、計算医学と計算
生命科学の大学院を運営しており、炎症 の医学研究に関する総額 3500 万ユーロ （約 40 億円）の「エクセレンス・クラ スター」の一翼も担っている。これら 2 つのプログラムは、連邦政府から助成を 受けている。いずれも廃止される可能性 が高い、と同大学の Peter Dominiak 学 長は語る。

提案された予算削減は、州議会の承認 を必要とし、採決は 12 月に予定されて いる。しかし、一部の研究者は既に大学 を離れる準備を始めている。こてれによっ て大学は大きなダメージを受け、私が、 ここで研究を続ける意味がなくなりま す」と神経科学者Jan Born は話す。彼は、 今年の 3 月に、睡眠と記憶の研究により、 ドイッで最も栄誉あるライプニッツ賞を 受賞し、250 万ユーロ（約 2 億 8000 万 円）の研究助成金を受け取っている。

DFG と州立大学の協会であるドイッ 大学長会議（HRK）の両首脳は、リュー ベック大学の予算削減に懸念を示してい る。HRK の Margret Wintermantel 会 長は、シュレースヴィヒ＝ホルシュタイ ン州の Peter Harry Carstensen 首相 (ド イッキリスト教民主同盟）にあてた書簡 の中で、こう述べている。「このような 措置は、リューベック大学だけでなく、 シュレースヴィヒ = ホルシュタイン州、 ひいてはドイツ全土に負の影響が広範囲 に及ぶ失政といわざるを得ません」。

(翻訳 : 菊川要) 